\title{
炭素鋼ワッペン試験片を用いた 臨海コンビナート工場敷地内の大気腐食調査
}

\author{
井上博之 ${ }^{1) *}$, 松村浩行 ${ }^{2)}$, 小森一夫 ${ }^{3)}$, 小野雅史 ${ }^{3)}$, 朝倉 亮 $^{4)}$ \\ 1) 大阪府立大学 大学院工学研究科 \\ 2) 堺市消防局 予防部 \\ 3) 三井化学株式会社 生産・技術本部 エンジニアリングセンター \\ 4) 日鉄テクノロジー株式会社 尼崎事業所
}
Investigation of the Atmospheric Corrosion in the Factory Site of a Littoral Industrial Complex Using Carbon Steel Adhesive-backed Test Coupons

\author{
Hiroyuki Inoue $^{1) *}$, Hiroyuki Muramatsu ${ }^{2)}$, Kazuo Komori ${ }^{3)}$, Masashi Ono ${ }^{3)}$ and Ryo Asakura ${ }^{4)}$ \\ 1) Graduate School of Engineering, Osaka Prefecture University \\ 2) Fire Prevention Department, Sakai City Fire Bureau \\ 3) Engineering Div, Production and Technology Center, Mitsui Chemicals Inc. \\ 4) Amagasaki Unit, Nippon Steel Technology Co., Ltd
}

\begin{abstract}
*責任著者(Corresponding Author) ＝599-8531 堺市中区学園町 1-1(1-1 Gakuen-cho, Naka-ku, Sakai, 599-8531, Japan) Email: hiro@mtr.osakafu-u.ac.jp
\end{abstract}

\begin{abstract}
The atmosphere corrosion tendency across a factory site in a littoral industrial complex was investigated using the carbon steel adhesive-backed test coupons. 150 test coupons of carbon steel were placed in the researched factory site and exposed to the atmosphere for a year. There was a tendency that the corrosion rate of the test coupons decreased with the logarithm of distances from the coastline. The corrosion of the test coupons was accelerated at the places of the high humidity such as around cooling towers. It is thought that the atmospheric corrosion test with the adhesive-backed test coupons is effective as technique to evaluate the tendency of an environmental corrosiveness in factory sites.
\end{abstract}

Key words : atmospheric corrosion, littoral industrial area, carbon steel, simplified measurement, adhesive-backed test coupon, adhered salt

\section{1. 緒}

\section{言}

臨海コンビナートの工場は，海洋からの飛来塩分の影 響により，鋼構造物の外面腐食が進行し易い. 工場内の 設備の大半は鋼構造物であることから, 特に, 経年化し た施設では，設備の外面腐食対策が保全の重要課題と なっている。

外面腐食対策の難しさの一つは, その対象が広範囲 (事 実上，屋外の設備全体)に及ぶことにある。このため対 策を適切に行うには, 予め, 敷地内での場所による鋼材 の大気腐食速度の傾向を把握し, 必要な個所に保全の予 算・人員を重点的に配分することが望まれる.

近年，橋梁の設置場所や部位毎の環境の腐食性を簡易 に評価する試験法として，ワッペン式試験片を用いた暴 露試験法が注目されている ${ }^{1), 2)}$ 。この試験法では, 評価
対象と等価な材料の小片を試験片として用いる．試験片 の裏面全体を両面テープで構造物などに接着して大気暴 露試験を行い, 暴露前後での質量変化から, 暴露個所の 環境の腐食性を評価する。

本調査では，ワッペン式試験片を用いた暴露試験法を 用いて，モデルとした臨海コンビナート工場内の一部の 区域で，場所による，鋼材に対する大気腐食環境の厳し さの違いや分布の傾向を解析した.

\section{2. 方法}

\section{1 試験片の寸法と仕上げ}

ワッペン式試験片 (以下，「試験片」とする)には，表 面が $50 \times 50 \mathrm{~mm}$ ，厚さが $2 \mathrm{~mm}$ の SS400 鋼板を用いた. 使用した鋼板の化学組成を Table 1 に示す。試験片の暴 露面(両面テープで接着しない側の表面)は微鏡面仕上げ

Table 1 Chemical composition of the test coupon.

\begin{tabular}{llllll}
$\mathrm{C}$ & $\mathrm{Si}$ & $\mathrm{Mn}$ & $\mathrm{P}$ & $\mathrm{S}$ & \multirow{2}{*}{$(w t \%)$} \\
\cline { 1 - 5 } 0.063 & 0.02 & 0.42 & 0.016 & 0.003 & \\
$\mathrm{Cr}$ & $\mathrm{Ni}$ & $\mathrm{Cu}$ & $\mathrm{Mo}$ & $\mathrm{V}$ & $\mathrm{Ti}$ \\
\hline 0.15 & 0.07 & 0.20 & 0.03 & 0.001 & $<0.001$
\end{tabular}

第 66 回材料と環境討論会(札幌, 2019 年)で発表 
とした．試験片の角部はいずれも面取り仕上げとした.

\section{2 試験片の設置}

試験片は，発泡ブチルゴムシートを基材とした厚さ $0.75 \mathrm{~mm}$ の耐候性の両面テープを用いて，その片面全体 を構造物に接着して設置した。設置個所は，階段の踏み 板の裏側などの，直接の雨がかりが無い場所とした．暴 露面を下向とし，地面と平行に設置した。 また，設置個 所が雨水のみず道と交差しないよう留意した。構造物へ 直接，接着するのが困難な箇所については, Fig. 1 に示 す, ステンレス鋼製の, 底の開いた容器と垂直板からな る覆いを用いて試験片を設置した。試験片は, 容器部の 天板の内側に上述の両面テープで貼り付けた。試験片を 貼り付けた覆い本体を, 構造物に, 暴露面が下向きでか つ地面と平行となる角度で固定した。

Fig. 2 の (A) と (B) に試験片の設置例を示す. それぞ れ，試験片を構造物へ直接接着した例，および覆いを介 して設置した例である，下記の 3.2 節で議論するが，海 岸に近い場所では, 試験片の設置個所が，海側あるいは 山側のいずれの方向にひらかれているかによって，腐食 速度に有意な差が生じた。ひらかれている方向は, 設置 個所周辺の建屋や覆いの垂直板の, 海岸に対する角度に よって分類した. Fig. 2 の(A) は, 背面の壁が設置個所 に対して陸側となるため, 海側にひらかれた個所に分類 される. Fig. 2(B) は, 写真の右が海側となるため, ポー ルの左および右に取り付けられた覆いは，それぞれ陸側 および海側にひらかれた設置個所となる。

\section{3 試験片の腐食速度および付着塩分の測定}

暴露後の試験片の質量測定は, クエン酸水素二アンモ ニウム水溶液で除錆してから行った．暴露前後での試験 片の質量変化ならびに暴露日数, 試験片の片面と側面(以 下「暴露面」とする)の面積から $\mathrm{mm} / \mathrm{y}$ 単位で腐食速度

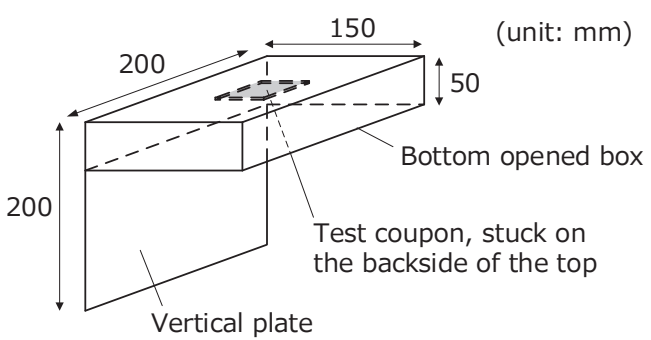

Fig. 1 Schematic illustration of the shelter for the test coupon.
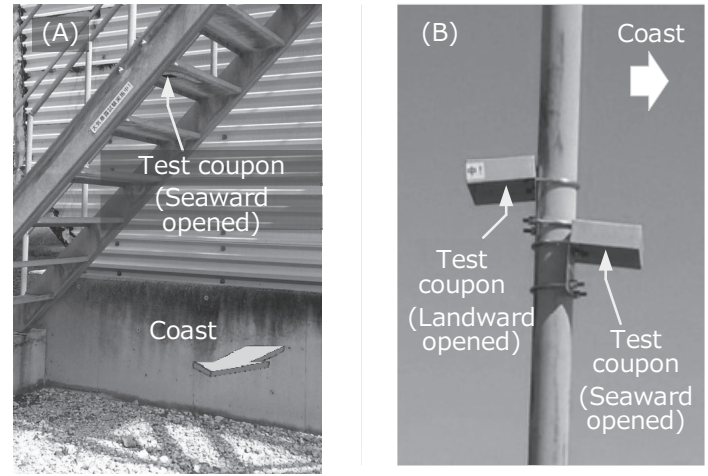

Fig. 2 Methods for the installation of the test coupon.
を計算した。

上述の暴露後の除錆作業に先立ち, 暴露面に付着して いる付着塩分量を測定した，暴露面の所定面積に一定体 積の純水を滴下して付着の塩分を溶解した後, この水溶 液の電気伝導度を測定し, 付着の水可溶性塩分量を計算 した．塩分量と純水の滴下面積から, $\mathrm{mg} / \mathrm{m}^{2}$ 単位で付 着塩分量を求めた。

\section{4 試験片の設置個所と暴露期間}

Fig. 3 に，対象とした工場の敷地および試験片を設置 した区域を示す。工場は堺泉北臨海工業地帯に立地して いる．敷地の北西が大阪湾に通じる入り江に，東側が道 路を挟んで運河に，それぞれ面している．他の方向は， 南側の道路を除き，隣接の他工場の敷地と接している. 試験片は，図に灰色で示したZone A ならびにZone B, Zone Cの各区域に，総計 150 枚を設置した，Zone A は 海岸線および海岸線と直交する工場内の道路に沿った区 域であり，計 96 枚を設置した. Zone B は隣接の工場敷 地との境界の内側の道路に沿った区域であり, 計 36 枚 を設置した. Zone Cの各区域は, 工場内の装置近傍の 屋外であり，残りの 18 枚を設置した。また参照デー夕 を得るため, 敷地外の 2 ヶ所の庁舎の計 6 個所に, 同じ く試験片を設置した。両庁舎は, 工場の北東の敷地境界 から北北東に $2.8 \mathrm{~km}$ ，および北東に $4 \mathrm{~km}$ のそれぞれ沿 岸部に位置する。図中の, 番号を付けて示した各場所 は，後述の 3.1 と 3.2 節で注目する試験片の設置個所で ある。

試験片の暴露期間は 2017 年 10 月からの 1 年間 $(365 \pm$ 7 日以内) とした。 工場内に設置した試験片の有効回収枚

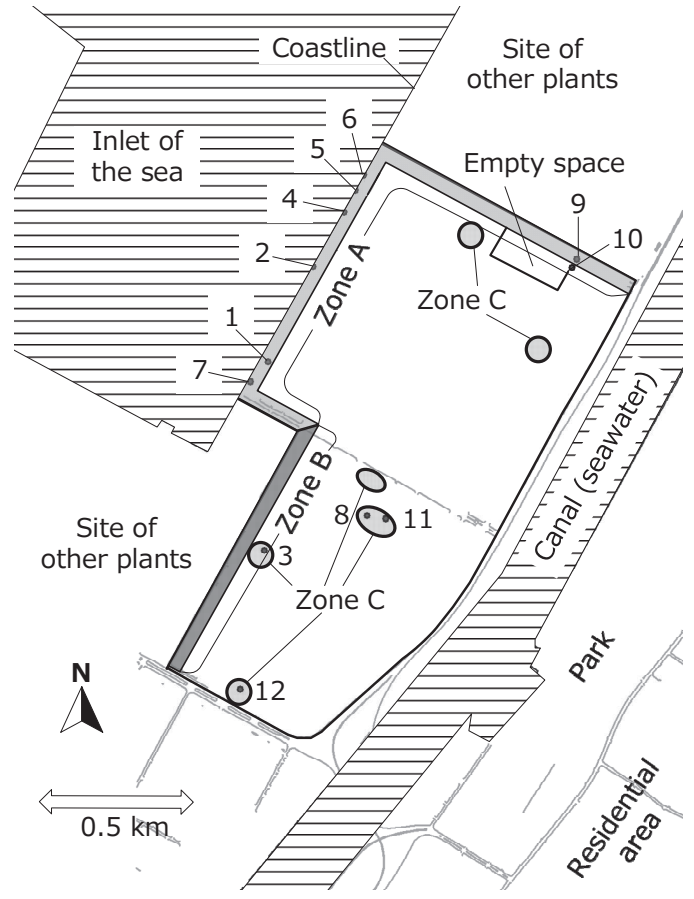

Fig. 3 Map of the researched plant and the adjacent areas. The gray-filled sections show the zones where the test coupons were placed in. The numerals in the figure indicate the installation position of the specific testcoupons, of which results are to be separately discussed in the section 3.2 and 3.3 . 
数は 148 枚であった．ただし内 4 枚は，設備管理の都合 などにより，暴露後 155 日ならび 338 日で回収した。庁 舎に設置した試験片の暴露期間は 2017 年 10 月からの 364 日とした.

工場内での試験片の設置個所の高さは, 原則, 地上か ら $1.5 \mathrm{~m}$ から $3 \mathrm{~m}$ の範囲内とした。ただし, 設置個所の 都合上，同高さを越える $7.5 \mathrm{~m}$ と $5 \mathrm{~m}$ の 2 個所および, 同じく下回る 0.4 から $1.3 \mathrm{~m}$ の 11 個所にも試験片を設置 した。これら 13 個所の試験片の腐食速度および付着塩 分量は, いずれも, 全試験片の腐食速度と付着塩分量の 回帰直線(後述の Fig. 5) に比較的近い值であった ${ }^{\dagger}$ 。この ため, 上記の 13 個所の結果も, 他の $1.5 \mathrm{~m}$ から $3 \mathrm{~m} の$ 高さに設置された試験片の結果と区別せず，以下の解析 に供した。

\section{3. 結 果 と考察}

\section{1 海岸線からの距離と試験片の腐食速度との関係}

臨海部での普通鋼の腐食は, 一般に, 海洋から飛来 し，表面付着した海塩粒子によって促進される，海塩粒 子による大気腐食の促進の程度は, 海岸からの距離と強 い相関がある ${ }^{3)}$.このため, 本調査で工場内に設置した 試験片について, 腐食速度と設置個所の海岸線からの距 離の関係を検討した。結果を Fig. 4 に示す。図中の，四 角のプロットは, 概ね海側にひらけている個所に設置さ れた試験片の腐食速度を示す。一方，白丸は，概ね陸側 にひらけている個所での結果である。なお，回収後の試 験片は，目視で観察した限り，いずれも表面全体にわ たって均等に発錆が進行していた.

Fig. 4 に示したと抢り，海岸に近い場所では，海岸線

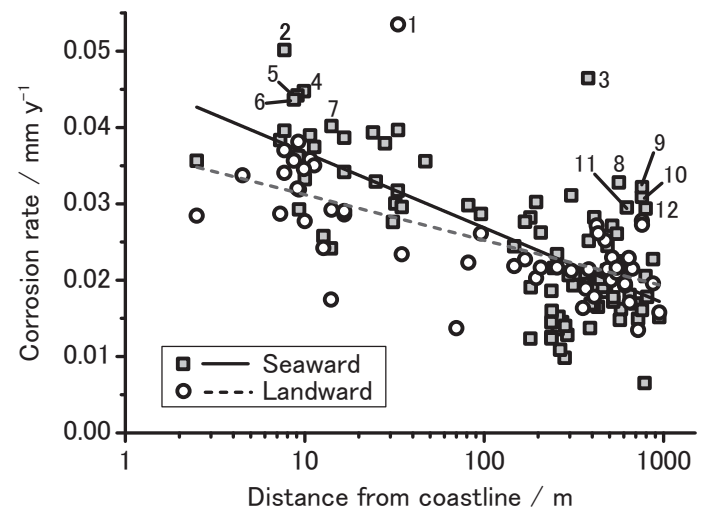

Fig. 4 Change in corrosion rate with the logarithm of distances from the coastline to where the test coupons were placed. The data were classified into two groups with the orientations for the sea; "Seaward" and "Landward" were the groups of which data were measured where the surroundings opened to a seaward and a landward, respectively. The numerals by some specific data indicate the installation position of the specific test-coupons, corresponding to those in Fig. 3 . The solid and the broken lines indicate the regression lines on the corrosion rates with the logarithm of the distances for the two groups, respectively.

† 13 個所の腐食速度の平均および最大值は，それぞれ $0.018 \mathrm{~mm} / \mathrm{y}$ と $0.029 \mathrm{~mm} / \mathrm{y}$, 同じく付着塩分量は, $28.0 \mathrm{mg} / \mathrm{m}^{2}$ と $52.2 \mathrm{mg} / \mathrm{m}^{2}$ であった.
からの距離の対数に応じて腐食速度が減少する傾向が認 められた．図中の実線および破線の直線は，それぞれ海 側および陸側にひらけている個所での，距離の対数を変 数とした腐食速度の回帰直線である. 両直線の関係よ り，海岸線からの距離が $200 \mathrm{~m}$ 程度までは，海側にひら けた個所の方が, 同じく陸側と比較し腐食速度が高い傾 向にある. $300 \mathrm{~m}$ 以遠では, 回帰直線は, 陸側にひらけ た個所の方が海側よりも高い值となっている。しかし， これは海岸に近い場所のデータの影響を受けた結果であ り，プロットされたデー夕点の分布を見ると，海岸線か ら $200 \mathrm{~m}$ を越える区域では，ひらけた方向による腐食速 度の違いは無いと推察される。

Fig. 4 の結果で, $0.04 \mathrm{~mm} / \mathrm{y}$ 以上の最も腐食速度が高 い 7 点について, 各デー夕点の横に, その速度の順に 1 から 7 の番号を記載した。また，海岸線から遠い位置に も関わらず腐食速度が比較的高い 5 点 $(500 \mathrm{~m}$ 以遠でか つ $0.03 \mathrm{~mm} / \mathrm{y}$ 以上)についても注目することとし, 同じ くその速度の順に 8 から 12 の番号を記載した。これら の番号の試験片の設置個所は, Fig. 3 の 1 から 12 の番号 の場所となる. Fig. 3 に示されていると打り, 最も腐食 速度が高い, 番号 1 から 7 の試験片の設置個所は, 番号 3 を除くと, いずれも海岸沿いの道路に沿った区域に位置 する. 番号 3 ならびに 8 から 12 の内, 番号 9 と 10 を除 く試験片の設置個所は, いずれも冷却塔の近傍であった. 番号 9 と 10 の設置個所は，幅と長さがそれぞれ $0.1 \mathrm{~km}$ と $0.25 \mathrm{~km}$ の空地(運動場ならびに駐車場)の陸側の端部 であった.

\section{2 試験片の付着塩分量と腐食速度との関係}

Fig. 5 に試験片の付着塩分量と腐食速度の関係を示 す。四角㧍よび白丸の各プロットは, Fig. 4 と同じく, それぞれ工場内の海側あるいは陸側にひらけた個所に設 置された試験片の結果を示す。三角のプロットは, 工場 外の, 庁舎に設置された試験片の結果である. 眓中の実 線ならびに破線，点線の各直線は，それぞれ工場内の海

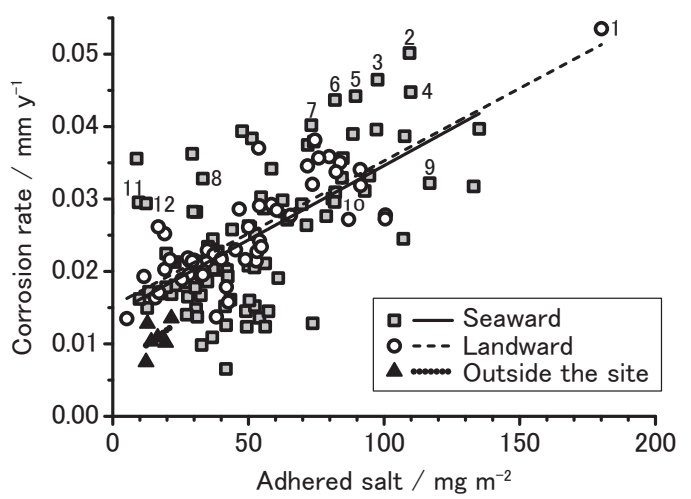

Fig. 5 Relationship between the corrosion rate of the test coupons and amount of salt adhered on them. The data obtained inside the researched plant were classified into the two groups as for Fig. 4. The results measured outside the plant were also plotted. The numerals by some specific data indicate the places for the specific testcoupons in Fig. 3. The solid, the broken and the dotted lines show the regression lines on the corrosion rates with amount of the adhered salt for the two groups and the data obtained outside the site respectively. 
側と陸側にひらけている個所および工場外の庁舎での， 付着塩分量を変数とした腐食速度の回帰直線である. 工 場内での結果に対する 2 つ回帰直線が示すとおり，試 験片の腐食速度は，付着塩分量に応じて増加した。ただ し，任意の付着塩分量での腐食速度には，2 から 4 倍も のばらつきがある。この結果は，付着塩分量は腐食速度 の支配因子の一つではあるものの，他に有意に影響する 因子が存在することを示唆している.

腐食速度が最も高い(約 $0.04 \mathrm{~mm} / \mathrm{y}$ 以上) 番号が 1 から 7 の 7 点の試験片は, 番号 3 を除くと, 前節で述べたと おり, いずれも海岸線に沿った場所に設置されていた。 海岸近傍は海水面に近いため, 飛来塩分量だけではな く, 湿度も高いと推測される. Fig. 5 に示したとおり, 番号 2 ならびに番号 4 から 7 の各試験片の腐食速度が, 同じ付着塩分量の中で最も高い水準となったのは，高湿 度であったため表面の需れ時間が長くなり，腐食反応が 長時間に渡って持続されたことに起因すると考えられる。

番号 1 の試験片の付着塩分量が, 上述の番号 2 ならび に番号 4 から 7 での結果と比較し 2 倍程度高いにも関わ らず, 腐食速度が, 回帰直線に沿った平均的な水準と なったのは, 海岸線からの距離が $33 \mathrm{~m}$ と他よりも遠かっ たため, 湿度が低く, 試験片表面の需れ時間が比較的短 かった可能性が推察される，なお，番号 1 の付着塩分量 が, 他の試験片と比較し, 特に高くなった理由は不明で ある. 番号 1 の設置個所の周囲の状況は, 海岸線に沿っ た他の場所と同様であり，付着塩分が過多となる理由は 見いだせなかった。しかし，番号 1 と同じ位置で海側へ ひらいた個所に設置された試験片の塩分付着量も, 全体 の 2 番目に高い $135 \mathrm{mg} / \mathrm{m}^{2}$ であった. したがって，そ の機構は不明であるが，番号 1 の設置個所は，飛来塩分 量が特異的に高くなる“ホットスポット”であったと推 測される。ワッペン式試験片を用いた暴露試験法は, 簡 易に環境の腐食性を評価できることから，網羅的な評価 が可能であり，このような環境の特異点を探索するのに 有効な手法と言える.

番号 3 の試験片は，その設置個所が海岸線からの距離 が $300 \mathrm{~m}$ と比較的遠いにも関わらず付着塩分量が高い. 番号 3 の設置場所は冷却塔に隣接している, このため, 飛散した冷却水の付着および成分の濃縮が生じ, 結果と して水可溶性塩分量が増加したと推察される. 同地点に 設置された試験片の高い腐食速度は, これら冷却水由来 の塩分や冷却塔近傍の高湿度雲囲気によってもたらされ たと推測される。

番号 8 から 12 は，いずれも海岸線から $500 \mathrm{~m}$ 以上離 れた個所に設置されていたにもかかわらず，腐食速度は 概ね $0.03 \mathrm{~mm} / \mathrm{y}$ 以上の高い水準となっている. Fig. 5 で これら試験片の塩分付着量を確認すると，番号 9 および 10 は比較的高いが，8 ならびに 11,12 は低い水準となっ ている. 番号 9 および 10 の設置個所は，いずれも舗装 された広い駐車場に面している. 一方, 番号 8 ならびに 11，12 は，いずれも冷却塔に隣接した場所である．前者 の番号 9 および 10 は，海側の広範囲にわたって建物が 無いため, 飛来塩分量が高く, 結果として海岸線から離
れているにも関わらず，付着塩分量が比較的高くなった と推測される。ただし，舗装駐車場に面した比較的低湿 度の䨌囲気であったため, 試験片表面の濡れ時間が相対 的に短く, 結果として試験片の腐食速度は低い水準に抑 えられたと推察される。一方，後者の 8 ならびに 11,12 は冷却塔近傍の高湿度の䨌囲気であったため, 付着塩分 量が比較的低いにも関わらず，試験片の腐食速度が高く なったと考えられる。

\section{4. ま と め}

調査対象とした臨海コンビナートの工場では，海岸に 近い場所では, 海岸線からの距離の対数に応じて, 炭素 鋼の腐食速度が減少する傾向が認められた。また，海岸 線から $200 \mathrm{~m}$ 程度までの範囲では, 海側にひらかれた個 所の方が，陸側にひらかれた個所と比較し，炭素鋼の腐 食速度は概ね高かった. $300 \mathrm{~m}$ 以遠の個所では，ひらか れた方向影響は認められなかった，海岸に沿った個所で の高い腐食速度は，飛来塩分が多いだけではなく，䨌囲 気が高湿度に保たれ易いことが, その原因と推察される。

冷却塔に隣接する個所など, 高湿度の環境では, 海岸 線から遠く, 付着塩分が低い条件でも高い腐食速度と なった。また, 海側が空き地となっている個所では, 構 造物に隣接した場所と比較し, 飛来塩分量が高くなる傾 向が認められた。

試験片の腐食速度が特に高い，あるいは海岸からの距 離が遠いにも関わらず比較的高い速度を示した設置個所 について，その機構を解析した。その結果，1個所を除 き，いずれも飛来塩分量や湿度の観点から高い腐食の原 因が考察できた。この結果より，ワッペン式試験片を用 いた暴露試験法は, 臨海コンビナートの工場の, 場所に よる環境の腐食性の傾向を評価する手法として有効であ ると考えられる．特に，飛来塩分や湿度などの腐食環境 条件が特異的に厳しくなっている局所 (ホットスポット) を探索する手法としての活用が期待される.

\section{謝辞}

本調査は堺市産学公連携推進協議会からの委託で平成 28 年度から平成 30 年度に実施された「危険物プラント 等における腐食防止の高度化に資する技術の有効性検証 業務」の成果の一部である.

Fig. 3 は, 国土地理院の国土基盤情報の地図デー夕に 著者が必要な情報を追記して作成した。

\section{参 考 文 献}

1) M. Ohya, M. Takebe, N. Hirose, M. Furukawa, H. Ohno and H. Hasegawa, Zairyo-to-Kankyo, 64, p.315(2015).

2) K. Ishida, A. Imai, R. Ishi and H. Kihira, Bosei Kanri (Rust Prev. Control), 61, pp.92-96(2017).

3) JSCE, Fushoku B Boshoku handbook, Maruzen, p.190 (2000).

(Manuscript received December 2, 2019; in final form April 7, 2020) 
要 旨

ワッペン試験片を用いて臨海コンビナート工場敷地内の大気腐食傾向を調査した。調査の工場内に 150 枚の炭素鋼製の試験片を設置し， 1 年間の大気暴露を行った。海岸に近い場所では，海岸線からの距離の 対数に応じて試験片の腐食速度が減少する傾向があった. また, 冷却塔周辺などの高湿度䨌囲気の場所で は試験片の腐食が促進された。ワッペン式試験片を用いた暴露試験法は, 工場内での環境の腐食性の傾向 を評価する手法として有効であると考えられる。

キーワード 大気腐食, 臨海工業地帯, 炭素鋼, 腐食速度, 簡易測定, ワッペン試験片, 付着塩分 